\title{
The SERVQUAL instrument: reliability and validity in South Africa
}

\author{
Deon $\mathrm{Nel}^{*}$ \\ Graduate School of Business, University of Cape Town, Private Bag, Rondebosch, 7700 Republic of South Africa \\ Leyland F. Pitt \& Pierre R. Berthon \\ Department of Marketing and Strategy, Cardiff Business School, University of Wales, Cardiff, United Kingdom
}

Received June 1997

\begin{abstract}
The drive to measure service quality has become a major focus in many organizations, as the links between service quality and business performance have become more clear. Similarly, the development of SERVQUAL, an instrument for the measurement of service quality, has spurred much research in this area. Most of the research concerning SERVQUAL has focussed on the psychometric properties of reliability and validity. SERVQUAL has received considerable academic and practitioner research attention in South Africa; however, while isolated studies have commented on its robustness, none have considered SERVQUAL across a range of industries and settings using different approaches. The study reported here attempts to redress this. It reports the results of SERVQUAL studies across a range of organizations and examines issues of reliability and validity. A major conclusion is that SERVQUAL in a South African context generally possesses strong statistical properties but needs further refinement particularly to overcome problems of discriminant validity. Opportunities for further research are identified.
\end{abstract}

*Author to whom correspondence should be addressed.

\section{Introduction}

In the past few years there has been a proliferation of literature on the effective management of service organizations (Albrecht, 1988; Carlzon, 1987; Lovelock, 1983; Mills, 1986; Berry, Parasuraman \& Zeithaml, 1988; Zeithaml, Parasuraman \& Berry, 1990). A major feature of this has been the competitive focus on service quality, which has been very prominent in the services literature since 1985 (Leonard \& Sasser, 1982; Berry, Zeithaml \& Parasuraman, 1985; Uttal, 1987; Parasuraman, Zeithaml \& Berry, 1988; Langevin, 1988; Lewis, 1989). A number of authors (Buzzell \& Gale, 1987; Luchs, 1986; Thompson, De Souza \& Gale, 1985; Liswood, 1989; Baum, 1990; Berry, Zeithaml \& Parasuraman, 1990), have also highlighted that perceived higher service quality translates into substantially higher profits for services firms. Literature on quality in general, as well as that specific to services, stresses the importance of measuring and monitoring quality (Takeuchi \& Quelch, 1983; Martin, 1987; De Souza, 1989; Hensel \& Baumgarten, 1988; Davidow \& Uttal, 1989; Kierl \& Mitchell, 1990; Mangold \& Babakus, 1990). An early example of the measurement of service quality was the experience of a British bank discussed by Buswell (1983), which considered such aspects as knowledge of staff, communications, expertise of staff, willingness to lend, and branch design. Richardson \& Robinson (1986) assessed the functional quality of service (Gronroös, 1978) provided by bank staff in South Africa. Tansuhaj, Wong \& McCullough (1987) measured technical and functional items of quality of banks in Thailand.

The development of the SERVQUAL instrument (Parasuraman, Zeithaml \& Berry, 1988) offered services marketers, perhaps for the first time, an apparently reliable, valid device for the measurement of service quality. If service quality is to be a mechanism for retaining competitive advantage by differentiation as proposed (Porter, 1985; Day \& Wensley, 1988), then it has to be measured if it is to be managed. The rigorous development of the SERVQUAL instrument in the USA has led to its acceptance as a research tool in both aca- demic and commercial applications. However, recent work (for example, Carman, 1990; Cronin \& Taylor, 1992) has questioned some aspects of its general applicability, and more specifically, facets of its validity.

The management of service quality is stationed within wider issues of organizational structure, philosophy and culture that can also influence service delivery and ultimately customer perceptions of service quality (Bowen \& Schneider, 1988; Gronroös, 1984; Heskett, 1987; Zeithaml, Berry \& Parasuraman, 1988). This would seem to accentuate Carman's (1990) suggestion that SERVQUAL is not the last word on service quality measurement, and that much further work needs to be done in the field. There have as yet been few authoritative studies published as to the applicability of SERVQUAL outside the USA and with particular reference here, very few in South Africa (see for example Nel \& Boshoff, 1991; and Labadie \& Harrison, 1991, for studies published locally; and, Pitt, Oosthuizen \& Morris, 1992 for a study published internationally). The question may well be asked, is the SERVQUAL instrument, designed in the United States, essentially under American conditions, a reliable and valid measure of service quality in another country? In this article we present an examination of the reliability and validity of SERVQUAL in four studies, using the instrument under South African conditions.

Frequently the ideas about product quality are not always directly transferable to service quality, for as Parasuraman, Zeithaml \& Berry (1985) point out, service quality is more difficult for the consumer to evaluate than goods' quality. Perceptions of service quality result from a comparison of the consumer's expectations, with actual service performance. Quality evaluations are, therefore, not made solely on the outcome of the service, but also involve evaluations of the 'process' of service delivery. The customer obviously has fewer tangible cues when purchasing a service than when purchasing goods. Most researchers and practitioners would now concur that service quality involves a comparison by the customer of expectations with performance, and that obviously 
no one but the customer/consumer/client/user is able to make this definition (Boothe, 1990). According to Lewis \& Booms (1983), service quality is a measure of how well the service level delivered matches customers' expectations. Therefore delivering service quality means conforming to customers' expectations on a consistent basis. Gronroös (1982) contends that consumers compare the service they expect with their perceptions of the service they receive in their evaluation of service quality. Satisfaction with service can thus be related to the disconfirmation paradigm proposed by Churchill \& Surprenant (1982). This posits that satisfaction is related to the magnitude and path of the disconfirmation experience, where disconfirmation is related to the individual's initial expectations.

Disconfirmation theory has received much attention in the service quality (specifically), and customer satisfaction (generally) literature (see Assael \& Kamins, 1989; Bitner, 1990; Cronin \& Morris, 1989; Kamins \& Assael, 1987; Oliver, 1980; 1981; 1989; Oliver \& Bearden, 1985; Oliver \& DeSarbo, 1988; Oliver \& Swan, 1989; Swartz \& Brown, 1989; Tse \& Wilton, 1988; Wilton \& Myers, 1986; Olson \& Dover, 1976). Before discussing the 'quality as perception' approach which forms the base of the propositions to be discussed in this article (Parasuraman, Zeithaml \& Berry, 1988) it is therefore useful to consider the relationships between service quality, attitudes and satisfaction. Researchers have generally distinguished between two constructs, customer satisfaction and attitude. Customer satisfaction is the customer's post-purchase evaluation of a product/service offering (Hunt, 1977). The customer is satisfied when the offering exceeds expectations relative to competitive offerings, and is dissatisfied when the product/service does not perform as expected. Customer satisfaction or dissatisfaction is typically modelled as a function of disconfirmation, arising from discrepancies between prior expectations and actual performance (Cardozo, 1965; Olshavsky \& Miller, 1972; Olson \& Dover, 1979). Customer attitude, in contrast, alludes to an overall evaluation of the product/service, rather than to a global evaluation of a specific transaction (Holbrook \& Corfman, 1985; Olshavsky, 1985). It can thus be argued that satisfaction eventually becomes an input to a less dynamic attitude, although the distinction between the two can become somewhat confused for frequently provided services (Bolton \& Drew, 1991b). Attitude is the customer's global evaluation of the product/service offering, and the recent research in services marketing has centred on the customer's evaluation of the overall excellence or superiority of the service. This has been the focus of the work of Parasuraman, Zeithaml \& Berry (1985; 1988). This gap has been modified in subsequent research by measuring expectations on the desired and adequate (minimum) levels. By comparing these levels of expectations with customer perceptions of service delivery, a measure of service superiority (MSS) and measure of service adequacy (MSA) can be identified (Zeithaml, Berry \& Parasuraman, 1991).

There are thus two sides to the service quality equation namely expectations (Powers, 1988; Cadotte, Woodruff \& Jenkins, 1987; Cronin \& Morris, 1989; Swartz \& Brown, 1989), and perceptions (Becker \& Wellins, 1990; Bertrand, 1989; Hensel \& Baumgarten, 1988; LeBlanc \& Nguyen, 1988; Tabacchi \& Marshall, 1988; Gronroös, 1988). Perhaps the most widely recognized, and used definition of service quality today is that suggested by Parasuraman, Zeithaml \& Berry (1985), who define it, from the customer's point of view, as a gap between the customer's expectations of a serv. ice and the customer's perceptions of the service received.

\section{Service quality: development of a construct}

As authorities in the area of goods quality (Crosby, 1979; Garvin, 1983) have suggested, the quality of manufactured products can be measured in a (relatively) more objective way by such indicators as durability, reliability, aesthetics, and the number of defects. Service quality is a much more abstract and elusive construct because of the features unique to service, namely intangibility, heterogeneity, and the inseparability of production and consumption. As Parasuraman, Zeithaml \& Berry (1985) point out, the measurement of service quality is far less objective from a quantitative point of view. In the absence of objective measures, an appropriate approach for assessing the quality of a firm's service is therefore to measure consumers' perceptions of quality.

\section{SERVQUAL instrument: reliability and validity}

Parasuraman, Zeithaml \& Berry $(1985$; 1988) have defined the service quality construct as the discrepancy, or gap, between the consumer's expectations of a service, and his or her perceptions of the service received. They propose a 22item instrument, a questionnaire called SERVQUAL, as being suitable for measuring this construct. After the construct has been constitutively defined, its measurement definition determines the specific questions to be asked, and how numbers are to be assigned to these. Because the conclusions drawn about the construct are ultimately determined by the responses to the questions asked, it is necessary to consider the properties of the measurement instrument itself. There are two standard measurement criteria for asssessing the appropriateness of any measurement instrument: reliability and validity. Reliability indicates the precision of measurement scores, or how accurately such scores will be reproduced with repeated measurement. As such, reliability has to do with the extent to which measures are free from random error, and yield constant results. Coefficient alpha $(\alpha)$ (Cronbach, 1951) is the most commonly accepted formula for assessing the internal consistency of a multi-item measurement scale.

Broadly speaking, validity refers to the extent to which differences in observed measurement scores reflect true differences in the characteristic being measured, although, as will be indicated, there are a number of other important facets of validity which bear discussion. Peter (1981) argues that construct validity is a necessary condition for theory development and testing because construct validity pertains to the degree of correspondence between constructs and their measure. His overview (and the procedure suggested by Churchill, 1979) of construct validity and construct validation have been followed by a number of serious marketing researchers in recent years in the development of instruments for the measurement of marketing constructs. Peter (1981) indeed posits, that reliability is also an operational issue in the validation of constructs, and along with convergent validity, discriminant validity, and nomological validity are components of what he calls trait validity. Dillon, Madden \& Firtle (1987) also 
suggest that content validity be considered. Any serious attempts at determining and testing the reliability and validity of measuring instruments in marketing should therefore assess these components.

Content validity is an indication of the representativeness of the content of a measurement scale. It focusses on whether the scale items adequately cover the entire domain of the construct under study. Convergent validity, is for purposes of this article a similar component, and is based on the correlation between responses to maximally different measuring methods of gauging the same construct. Content validity of the SERV. QUAL instrument, for example, should be satisfied by this question: does the SERVQUAL scale appear to measure what it is supposed to? Convergent validity should be answered by this question: does a measure of service quality determined by SERVQUAL correspond with other measures of service quality?

Nomological validity refers to an observed relationship between measures purported to assess different (but conceptually related) constructs. If two constructs $\left(C_{1}\right.$ and $\left.C_{2}\right)$ are conceptually related, evidence that purported measures of each $\left(M_{1}\right.$ and $\left.M_{2}\right)$ are related, is usually accepted as empirical support for the conceptual relationship. Nomological validity in the case of the SERVQUAL scale is indicated if, in a factor analysis, items expected to load together actually do so. Discriminant validity is an indication of the extent to which the measurement scale is novel, and not simply a reflection of some other variable. Discriminant validity in the case of the SERVQUAL scale is indicated in a factor analysis, if the factors, and their items, are truly different from one another.

In their rigorous development of the SERVQUAL scale, Parasuraman, Zeithaml \& Berry (1988) subjected it to testing for reliability, and for the other dimensions of validity discussed above. In subsequent work in this regard, a number of authors (Carman, 1990; Babakus \& Boller, 1992; Brensinger \& Lambert, 1990; Finn \& Lamb, 1991; Pitt, Oosthuizen \& Morris; and partially by Lewis, 1991) have examined the reliability and validity of SERVQUAL under a variety of situations and in a number of industries.

\section{Measuring service quality}

Parasuraman, Zeithaml \& Berry (1988) operationalized their conceptual model of service quality by following the framework of Churchill (1979) for developing measures of marketing constructs. This resulted in a 22 -item instrument (SERVQUAL) for assessing customer perceptions of service quality in service and retailing organizations. Underlying the 22 items are five dimensions that the authors claim are used by customers when evaluating service quality, regardless of the type of service. These dimensions are:

- Tangibles: physical facilities, equipment, and appearance of personnel.

- Reliability: ability to perform the promised service dependably and accurately.

- Responsiveness: willingness to help customers and provide prompt service.

- Assurance: knowledge and courtesy of employees and their ability to inspire trust and confidence.

- Empathy: caring, individualized attention the firm provides its customers.
The authors concede that items that may be relevant to the discussion of service quality for one particular industry/firm may not be reflected in their generalized instrument. The instrument may, therefore, need to be reworded or augmented when applied in specific applications.

\section{SERVQUAL instrument}

The development of the SERVQUAL instrument, a multidimensional questionnaire for the assessment of service quality is described by Parasuraman, Zeithaml \& Berry (1988). The original questionnaire uses a 7-point Likert-type scale anchored on 'strongly disagree' (1) through to 'strongly agree' (7), with half the statements positively, and half negatively worded. The questionnaire was used to assess the service quality perceptions of customers who had recently used the services of five different types of service organizations (essentially following Lovelock's [1980] classification). Since 1990 (see Zeithaml, Parasuraman \& Berry, 1990), the SERVQUAL instrument has been changed in one important way: all items are positively stated and scored.

\section{SERVQUAL in some South African situations}

\section{Methodology}

Questions concerning the applicability of the SERVQUAL instrument would require it to be evaluated across a broad range, or typology, of organizations. Thus it is necessary to allocate specific types of organizations to the various dimensions of the typology used. In this series of studies, the Larsson-Bowen (1989) framework is used, which distinguishes between four basic service organization types according to the degree of customer disposition to participate, and the diversity of demand. As already stated, in the original development of the SERVQUAL instrument, the developers (Parasuraman, Zeithaml \& Berry, 1988) also used a typology, that of Lovelock (1980).

Replications of original studies are acceptable vehicles for the establishment of reliability and validity of instruments. In generally similar ways, the studies described here replicated parts of the original development process of the SERVQUAL questionnaire (Parasuraman, Zeithaml \& Berry, 1988), by testing the SERVQUAL instrument in four quite different situations. It should be noted that replicative studies do not need to be conducted in identical ways, nor is the data analysed, or presented, in exactly the same way each time. As Brown \& Gaulden (1984) point out, this is indeed acceptable practice in research, and frequently adds valuable insights if replication is to add to the development of theory. It is not absolutely essential that replications of studies be clones of those studies. The nature of the studies is described in Table 1.

\section{Hypotheses}

Five specific hypotheses regarding the applicability of the SERVQUAL instrument in South Africa are postulated:

$\mathrm{H}_{1}$ : That SERVQUAL will maintain its reliability under South African conditions (as evidenced by coefficients a, with alphas on dimensions and for the instrument exceeding the customary cut-off point of 0.7 [Carman, 1990]). 


\begin{tabular}{|c|c|c|c|c|}
\hline Larsson-Bowen category & Type 1 & Type II & Type III & Type IV \\
\hline Type of organization & Regional airline & Graduate business school & \multicolumn{2}{|c|}{ Short-term insurance broker Retail pharmacies } \\
\hline Survey methodology & $\begin{array}{l}\text { Questionnaires distributed to passengers } \\
\text { on flights from various centres }\end{array}$ & $\begin{array}{l}\text { Questionnaires distributed to } \\
\text { MBA (part-time and full-time) } \\
\text { students and executives }\end{array}$ & Mail survey & Mail survey \\
\hline Nature of questionnaire & $\begin{array}{l}\text { 22-statement SERVQUAL, amended by } \\
\text { addition of } 8 \text { service quality questions; } \\
\text { demographic items - e.g. age, gender, } \\
\text { occupation, frequency of flying etc. }\end{array}$ & $\begin{array}{l}\text { 22-statement SERVQUAL; } \\
\text { certain demographic items }\end{array}$ & $\begin{array}{l}\text { 22-statement SERVQUAL; } \\
\text { certain demographic items }\end{array}$ & $\begin{array}{l}\text { 22-statement SERVQUAL; } \\
\text { certain demographic items }\end{array}$ \\
\hline Size of sample & 400 & 246 & 500 & 2000 \\
\hline Effective response & 135 & 162 & 74 & 222 \\
\hline Effective response $\%$ & $33.75 \%$ & $65.85 \%$ & $14.8 \%$ & $11.1 \%$ \\
\hline
\end{tabular}

$\mathrm{H}_{2}$ : That SERVQUAL will maintain content validity under South African conditions. (The scale items will adequately cover the entire domain of the construct under study. Measures of service quality by SERVQUAL will be paired with similar overall assessments of service quality by the same respondents.)

$\mathrm{H}_{3}$ : That SERVQUAL will maintain convergent validity under South African conditions. (A measure of service quality determined by SERVQUAL will correspond with other measures of service quality. The $R^{2}$ in a multiple regression of the service quality dimensions on an overall assessment of service quality will be significant.)

$\mathrm{H}_{4}$ : That SERVQUAL will maintain nomological validity under South African conditions. (In a factor analysis of the items in the scale, items that are expected to load together will do so.)

$\mathrm{H}_{s}$ : That SERVQUAL will maintain discriminant validity under South African conditions. (In a factor analysis of the items in the scale, the factors that emerge will be truly different.)

\section{Results}

In this section of the article, the results of the reliability testing of SERVQUAL in each application are presented, together with assessments of the content, convergent, nomological and discriminant validities in each case.

\section{Reliability}

The alpha coefficients by dimension, and for the overall SERVQUAL instrument, are reported in Table 2 . It can be seen from the table that the alpha for the instrument as a whole, namely the SQI (Service Quality Index), achieved the commercially acceptable cut-off point of 0.7 , with alphas ranging form 0.70 in the case of the broker, to $=0.78$ in the case of the graduate business school. The dimension where the alpha coefficient tends to be low throughout is tangibles, which is in line with findings reported by Carman (1990), Parasuraman, Zeithaml \& Berry (1991), and Pitt, Oosthuizen \& Morris (1992) who all found tangibles to be the dimension evidencing the lowest alpha coefficient. In the case of the graduate business school, and the broker, the alphas for the assurance dimension are also under the 0.70 cut-off point. In general, however, SERVQUAL has performed well in these studies with regard to reliability as measured by coefficient alpha. $\mathrm{H}_{1}$ is therefore accepted.

\section{Content validity}

In order to assess content validity, respondents in all the studies were required to give an indication of their overall impression of the service quality of the organizations concerned. Table 3 shows the mean SERVQUAL scores for respondents, for each organization, grouped by their overall impression of service, and the SQIs (Service Quality Indexes) for respondents by overall impression of service quality.

These results indicate support for the content validity of the SERVQUAL instrument - SERVQUAL scores clearly become more positive as overall service impressions change from poor to excellent. $\mathrm{H}_{2}$ is thus accepted.

\section{Convergent validity}

In order to investigate convergent validity, multiple regression analyses were undertaken, using the overall service quality evaluation as the dependent variable, and the indices on the

Table 2 Instrument reliability: coefficient a for dimensions and overall index of service quality

\begin{tabular}{lcccc}
\hline Dimension & Airline & $\begin{array}{c}\text { Graduate } \\
\text { business school }\end{array}$ & $\begin{array}{c}\text { Shon-term } \\
\text { insurance broker }\end{array}$ & $\begin{array}{c}\text { Retail } \\
\text { pharmacies }\end{array}$ \\
\hline Tangibles & 0.62 & 0.79 & 0.53 & 0.65 \\
Reliability & 0.67 & 0.89 & 0.81 & 0.70 \\
Responsiveness & 0.79 & 0.85 & 0.79 & 0.80 \\
Assurance & 0.79 & 0.66 & 0.61 & 0.81 \\
Empathy & 0.75 & 0.79 & 0.78 & 0.79 \\
Overall scale & $\mathbf{0 . 7 2}$ & 0.78 & 0.70 & 0.75 \\
\hline
\end{tabular}

\begin{tabular}{|c|c|c|c|c|}
\hline $\begin{array}{l}\text { Overall } \\
\text { evaluation }\end{array}$ & Airline & $\begin{array}{c}\text { Graduate } \\
\text { business school }\end{array}$ & $\begin{array}{c}\text { Short-lerm } \\
\text { insurance broker }\end{array}$ & $\begin{array}{c}\text { Retail } \\
\text { pharmacies }\end{array}$ \\
\hline Poor & -3.43 & -2.24 & -2.34 & $0.02^{*}$ \\
\hline Fair & -2.19 & -1.04 & $-1.37-$ & 0.65 \\
\hline Good & -0.74 & -0.30 & -0.67 & -0.39 \\
\hline Excellent & -0.24 & -0.08 & -0.12 & -0.05 \\
\hline
\end{tabular}


five dimensions as the predictor variables. Evidence of the convergent validity of a measure is provided by the extent to which it correlates highly with other methods designed to measure the same construct (Churchill, 1979). While Table 3 provides superficial support for SERVQUAL in this respect, regression of overall service impressions with an overall SERVQUAL score yielded the results reported in Table 4 . In the table the $\mathbf{R}^{2}$ for the overall regression is reported, and the dimensions are reported for each study simply in terms of whether they were significant or not.

The $\mathbf{R}^{2}$ for each of the full regressions in all the studies are significant, as can be seen from Table 4 . In the case of the graduate business school study, while none of the dimensions was individually significant, the $\mathrm{R}^{2}$ is. In the other cases, the reliability dimension was significant. In general, however, it can be seen that SERVQUAL correlated well with the individual measures of service quality. $\mathrm{H}_{3}$ is thus accepted.

\section{Nomological validity}

To establish nomological validity of the SERVQUAL instrument, the data in all cases was subjected to factor analyses, with the number of factors established by the SAS MINEIGEN criterion, which extracts factors with eigenvalues greater than 1 , then followed by PROMAX rotation, as suggested by Carman (1990). The results of the procedures are reported in Tables $5 \mathrm{a}, 5 \mathrm{~b}, 5 \mathrm{c}, 5 \mathrm{~d}$, for the four organizations studied. For nomological validity to exist, the items expected to load together in a factor analysis, should do so. It will be noted that the factor analyses did not always result in a five-factor solution - the extraction procedure resulted in solutions ranging from three factors in the case of the retail pharmacies, through four in the case of the airline, to five in the cases of the business school and the broker.

It is apparent from the factor analysis in Table 5a that the service quality study in the case of the regional airline did not result in the same factors, or in the same item-to-factor loadings as in the original SERVQUAL questionnaire development. More importantly, the items that were expected to load together, did not. However, it will also be noted from Table 5a that the items correlate quite strongly with more that one factor in the table, so that in a sense, items that are expected to load together are at least correlated. It would thus seem that the SERVQUAL questionnaire does meet the requirement for being nomologically valid. The results of the procedure for the graduate business school are reported in Table Sb. In the

\begin{tabular}{lcccc}
\hline \multicolumn{4}{l}{ Table 4 Convergent validity } \\
\multicolumn{4}{l}{ Multiple regression of dimensions on overall evaluation of service quality } \\
\hline Measure & Airline & $\begin{array}{c}\text { Graduate } \\
\text { business school }\end{array}$ & $\begin{array}{c}\text { Short-term } \\
\text { insurance broker }\end{array}$ & $\begin{array}{c}\text { Retail } \\
\text { pharmacies }\end{array}$ \\
\hline $\mathrm{R}^{2}$ & $0.53^{\mathrm{h}}$ & $0.50^{\mathrm{h}}$ & $0.54^{\mathrm{h}}$ & $0.68^{\mathrm{h}}$ \\
Tangibles & $\mathrm{b}$ & $\mathrm{a}$ & $\mathrm{a}$ & $\mathrm{a}$ \\
Reliability & $\mathrm{b}$ & $\mathrm{a}$ & $\mathrm{b}$ & $\mathrm{b}$ \\
Responsiveness & $\mathrm{b}$ & $\mathrm{a}$ & $\mathrm{b}$ & $\mathrm{a}$ \\
Assurance & $\mathrm{a}$ & $\mathrm{a}$ & $\mathrm{b}$ & $\mathrm{b}$ \\
Empathy & $\mathrm{a}$ & $\mathrm{a}$ & $\mathrm{a}$ & $\mathrm{a}$ \\
\hline Significance levels: $\mathrm{a}=\mathrm{p}>0.05 ; \mathrm{b}=\mathrm{p}<0.05$ & & \\
\hline
\end{tabular}

table factor loadings below 0.25 were filtered out following the procedure suggested by Parasuraman, Zeithaml \& Berry (1988) - this may simplify visual analysis. The table shows nomological validity to apply quite strongly to four of the five dimensions - assurance being the exception. In overall terms, therefore, SERVQUAL can be regarded as having nomological validity for measuring service quality of a graduate business school.

The results of the factor analysis for the broker are reported in Table 5c. As can be seen, items that were expected to load together did so to a large extent. Five factors emerged, but were not exactly as predicted by the Parasuraman, Zeithaml \& Berry (1988) study, nor as clearly differential as might be expected. Generally, however, it can be accepted that the SERVQUAL questionnaire possesses nomological validity in the measurement of service quality in a Larsson-Bowen framework Type III organization, namely a short-term insurance broker. The results of the procedure for the chain of retail pharmacies are reported in Table $5 \mathrm{~d}$. The factor analysis procedure only resulted in the extraction of three factors, but generally the items that are expected to do so, load on to the same factors. There are some exceptions. Item 3, a tangibles item (appearance of employees), does not load with the other tan-

Table $5 a$ Results of airline service quality study factor analysis

\begin{tabular}{|c|c|c|c|c|c|}
\hline Item & Factor I & Factor 2 & Factor 3 & Factor 4 & Communality \\
\hline 1 & 0.36704 & 0.51014 & 0.44363 & 0.86796 & 0.79 \\
\hline 2 & 0.56008 & 0.50774 & 0.38458 & 0.79297 & 0.70 \\
\hline 3 & 0.42164 & 0.60796 & 0.49116 & 0.84028 & 0.79 \\
\hline 4 & 0.51721 & 0.33220 & 0.17364 & 0.64803 & 0.54 \\
\hline 5 & 0.60657 & 0.81664 & 0.37448 & 0.40993 & 0.68 \\
\hline 6 & 0.44799 & 0.77700 & 0.31587 & 0.46290 & 0.63 \\
\hline 7 & 0.38959 & 0.68897 & 0.46016 & 0.47678 & 0.54 \\
\hline 8 & 0.73291 & 0.53541 & 0.61143 & 0.32334 & 0.64 \\
\hline 9 & 0.62534 & 0.68356 & 0.63855 & 0.29560 & 0.64 \\
\hline 10 & 0.75468 & 0.52584 & 0.67519 & 0.36238 & 0.71 \\
\hline 11 & 0.41169 & 0.41898 & 0.93365 & 0.35363 & 0.87 \\
\hline 12 & 0.43290 & 0.47759 & 0.91809 & 0.38958 & 0.85 \\
\hline 13 & 0.82690 & 0.55936 & 0.44925 & 0.37387 & 0.69 \\
\hline 14 & 0.74282 & 0.81110 & 0.51963 & 0.32761 & 0.77 \\
\hline 15 & 0.84812 & 0.64634 & 0.38443 & 0.24125 & 0.77 \\
\hline 16 & 0.89027 & 0.61278 & 0.47407 & 0.32680 & 0.81 \\
\hline 17 & 0.70148 & 0.78209 & 0.46636 & 0.45193 & 0.69 \\
\hline 18 & 0.87123 & 0.63749 & 0.42171 & 0.43437 & 0.78 \\
\hline 19 & 0.68557 & 0.82407 & 0.42763 & 0.48057 & 0.73 \\
\hline 20 & 0.82835 & 0.65130 & 0.35244 & 0.39426 & 0.72 \\
\hline 21 & 0.71434 & 0.79237 & 0.41843 & 0.42089 & 0.71 \\
\hline 22 & 0.59894 & 0.47920 & 0.62230 & 0.51261 & 0.56 \\
\hline 23 & 0.81056 & 0.43392 & 0.45216 & 0.40077 & 0.69 \\
\hline 24 & 0.74035 & 0.81392 & 0.41611 & 0.38724 & 0.75 \\
\hline 25 & 0.83215 & 0.70093 & 0.36452 & 0.47212 & 0.76 \\
\hline 26 & 0.86056 & 0.65187 & 0.39617 & 0.51734 & 0.79 \\
\hline 27 & 0.74445 & 0.48524 & 0.28894 & 0.44273 & 0.59 \\
\hline
\end{tabular}


Table 5b Results of graduate business school service quality study - factor analysis following PROMAX rotation

\begin{tabular}{|c|c|c|c|c|c|c|c|}
\hline & & Factor 1 & Factor 2 & Factor 3 & Factor 4 & Factor 5 & $\begin{array}{c}\text { Commo- } \\
\text { nality }\end{array}$ \\
\hline \multirow[t]{4}{*}{ Tangibles } & 1 & 0.38 & - & - & - & 0.62 & 0.59 \\
\hline & 2 & - & - & - & - & 0.81 & 0.75 \\
\hline & 3 & - & 0.65 & - & - & 0.37 & 0.63 \\
\hline & 4 & 0.48 & - & - & - & 0.49 & 0.54 \\
\hline \multirow[t]{5}{*}{ Reliability } & 5 & 0.83 & - & 0.27 & - & - & 0.81 \\
\hline & 6 & 0.70 & - & - & 0.28 & - & 0.63 \\
\hline & 7 & 0.83 & - & - & - & - & 0.80 \\
\hline & 8. & 0.85 & - & - & - & - & 0.81 \\
\hline & 9 & 0.47 & - & - & 0.27 & - & $0.4 \mathrm{I}$ \\
\hline \multirow[t]{4}{*}{$\begin{array}{l}\text { Responsive- } \\
\text { ness }\end{array}$} & 10 & 0.62 & 0.38 & 0.37 & - & - & 0.67 \\
\hline & 11 & 0.48 & 0.58 & - & - & - & 0.68 \\
\hline & 12 & 0.27 & 0.74 & - & 0.26 & - & 0.74 \\
\hline & 13 & - & 0.65 & - & 0.45 & - & 0.71 \\
\hline \multirow[t]{4}{*}{ Assurance } & 14 & - & - & - & 0.73 & - & 0.61 \\
\hline & 15 & 0.52 & 0.29 & - & 0.48 & - & 0.60 \\
\hline & 16 & - & 0.61 & 0.26 & - & - & 0.52 \\
\hline & 17 & - & - & - & 0.50 & - & 0.40 \\
\hline \multirow[t]{5}{*}{ Empathy } & 18 & 0.29 & 0.41 & 0.63 & - & - & 0.69 \\
\hline & 19 & - & - & 0.69 & - & - & 0.54 \\
\hline & 20 & - & 0.27 & 0.78 & - & - & 0.77 \\
\hline & 21 & 0.30 & - & 0.56 & 0.37 & 0.35 & 0.66 \\
\hline & 22 & 0.54 & - & - & 0.47 & - & 0.58 \\
\hline $\begin{array}{l}\text { Variance } \\
\text { explained }\end{array}$ & & $22 \%$ & $13 \%$ & $11 \%$ & $10 \%$ & $9 \%$ & $\begin{array}{l}\text { Total: } \\
65 \%\end{array}$ \\
\hline
\end{tabular}

gibles items; item 9, a reliability item (error-free records), does not load with the other reliability items; item 10 , a responsiveness item (employees telling exactly when the service will be performed), does not load with the other responsiveness items; and, item 19, an empathy item (convenient operating hours), does not load with other empathy items. In general, however, it can again be said that the SERVQUAL questionnaire possesses nomological validity for the measurement of service quality. As overall nomological validity has been demonstrated in all cases, $\mathrm{H}_{4}$ is accepted.

\section{Discriminant validity}

For an instrument to possess discriminant validity, the factors need to be truly different from each other. The robustness of the PZB factors are somewhat in doubt on this criterion, according to Carman (1990). Discriminant validity is an indication of the extent to which the measurement scale is novel, and not simply a reflection of some other variable. In the factor analyses in Tables 5, some doubt is cast on the SERVQUAL questionnaire's discriminant validity. One approach to evaluating the instrument in this regard is to use the reference axis correlations, which are produced as part of the SAS factor analysis output. For the regional airline this will be seen in Table 6a, where a high $(-0.47775)$ partial cor-

\begin{tabular}{|c|c|c|c|c|c|}
\hline Item & Factor 1 & Factor 2 & Factor 3 & Factor 4 & Factor 5 \\
\hline 1 & - & - & - & - & 0.7824 \\
\hline 2 & - & - & - & 0.43032 & 0.62592 \\
\hline 3 & - & - & - & 0.76284 & - \\
\hline 4 & 0.35208 & - & 0.33252 & 0.46944 & 0.37164 \\
\hline 5 & 0.84108 & 0.33252 & - & - & - \\
\hline 6 & 0.79218 & 0.5868 & - & - & - \\
\hline 7 & 0.7824 & 0.45966 & 0.38142 & - & - \\
\hline 8 & 0.88998 & 0.42054 & 0.3423 & - & - \\
\hline 9 & 0.61614 & 0.49878 & 0.44988 & - & - \\
\hline 10 & 0.67482 & 0.489 & 0.38142 & - & - \\
\hline 11 & 0.7824 & 0.60636 & 0.489 & - & - \\
\hline 12 & 0.66504 & 0.70416 & 0.51834 & - & - \\
\hline 13 & 0.6357 & 0.62592 & 0.57702 & - & - \\
\hline 14 & 0.3912 & 0.42054 & 0.75306 & - & - \\
\hline 15 & - & -0.79218 & - & - & \\
\hline 16 & 0.32274 & 0.5379 & 0.489 & 0.59658 & - \\
\hline 17 & 0.6357 & 0.55746 & 0.45966 & - & - \\
\hline 18 & 0.50856 & 0.82152 & 0.36186 & - & - \\
\hline 19 & 0.33252 & 0.65526 & - & - & 0.30318 \\
\hline 20 & 0.4401 & 0.79218 & 0.37164 & 0.2934 & - \\
\hline 21 & 0.62592 & 0.67482 & 0.65526 & - & - \\
\hline 22 & 0.64548 & 0.74328 & 0.489 & - & - \\
\hline
\end{tabular}

relation between factor one and two is indicated. It would thus seem that the SERVQUAL questionnaire as used in the study of service quality in a regional airline, is questionable with regard to discriminant validity under South African conditions. Further stronger evidence for this is provided by the high correlations of the items with more than one factor in Table 5a.

For the graduate business school, rather than employ reference axis correlations, item scores on factors and commonalties were used as a means of visual assessment of discriminant validity. Here, some anomalous results are apparent in the factor analysis in Table $5 \mathrm{~b}$, which would tend to reduce discriminant validity - items 3 (the physical appearance of staff), and 4 (appearance of materials) are cases in point. The items load strongly onto more than one factor, and the commonality scores of 0.63 and 0.54 respectively are quite low. Other items where there appear to be non-discrimination are statements $10,11,13,15,18,21$ and 22 . Generally, it would not be unfair to say that in this case, the SERVQUAL questionnaire is lacking in discriminant validity. Similar discriminant validity problems have been reported in studies across the world in the computer manufacturing, retailing, auto insurance and life insurance industries (Parasuraman, Zeithaml \& Berry, 1994).

For the short-term insurance broker, the factor analysis in Table 5c, casts some doubt on the SERVQUAL questionnaire's discriminant validity. An indication of the weakness of the instrument in this area was once more provided by 


\begin{tabular}{|c|c|c|c|c|}
\hline Item & Factor 1 & Factor 2 & Factor 3 & Communality \\
\hline 1 & 0.40021 & 0.41809 & 0.82876 & 0.69 \\
\hline 2 & 0.53737 & 0.51196 & 0.90137 & 0.81 \\
\hline 3 & 0.72351 & 0.49843 & 0.63762 & 0.60 \\
\hline 4 & 0.60107 & 0.63004 & 0.79167 & 0.69 \\
\hline 5 & 0.53070 & 0.92412 & 0.48777 & 0.86 \\
\hline 6 & 0.66726 & 0.77489 & 0.58603 & 0.67 \\
\hline 7 & 0.68922 & 0.76598 & 0.51957 & 0.66 \\
\hline 8 & 0.57341 & 0.92761 & 0.45453 & 0.87 \\
\hline 9 & 0.60780 & 0.49739 & 0.49772 & 0.41 \\
\hline 10 & 0.65243 & 0.76192 & 0.58883 & 0.65 \\
\hline 11 & 0.89150 & 0.59786 & 0.56101 & 0.80 \\
\hline 12 & 0.90782 & 0.60533 & 0.48222 & 0.83 \\
\hline 13 & 0.83973 & 0.54560 & 0.39039 & 0.72 \\
\hline 14 & 0.92625 & 0.56338 & 0.51510 & 0.86 \\
\hline 15 & 0.85254 & 0.59181 & 0.56337 & 0.74 \\
\hline 16 & 0.92445 & 0.54143 & 0.46100 & 0.86 \\
\hline 17 & 0.83940 & 0.53576 & 0.49008 & 0.71 \\
\hline 18 & 0.87519 & 0.61682 & 0.55048 & 0.78 \\
\hline 19 & 0.52988 & 0.69502 & 0.66520 & 0.59 \\
\hline 20 & 0.85593 & 0.66746 & 0.53382 & 0.76 \\
\hline 21 & 0.78902 & 0.76449 & 0.59808 & 0.75 \\
\hline 22 & 0.89017 & 0.60697 & 0.54596 & 0.80 \\
\hline
\end{tabular}

reference axis correlations, which indicated a high $(-0.437)$ partial correlation between factors 1 and 2 . A further pointer in this regard is the high coefficient alpha (0.9188) obtained by a correlation analysis of reliability and responsiveness items. A further correlation analysis on all 22 items in the instrument yielded a final indication of its questionable discriminant capability in terms of the five dimensions proposed by Parasuraman, Zeithaml \& Berry (1988). This analysis yielded a coefficient alpha of 0.919. Parasuraman, Zeithaml \& Berry (1988), used similar analyses to purify the instrument, where items with low corrected item-to-total correlations were deleted. This approach would result in the removal of all the tangibles items, and also item 15 (customers will feel safe in their transactions) in this study.

In the case of the retail pharmacies, a cursory examination of the factor analysis in Table 5d would seem to indicate that all the items load rather strongly on to all of the factors, suggesting that the factors may in fact be highly correlated - in fact, the lowest loading of an item onto a factor is that of item 1 onto Factor 1, 0.40021. This is in fact confirmed by examination of the reference axis correlations as presented in Table $6 \mathrm{~b}$, in which it can be seen that the factors correlate quite highly with each other. In the case of Factors 1 and 2 the correlation is 0.4625 , and other correlations exceed 0.3. As discriminant validity has not been demonstrated in any of the studies described here, $\mathrm{H}_{5}$ is rejected.

In summary then it can be said that the SERVQUAL instrument demonstrated generally acceptable levels of reliability; that content and convergent, as weil as nomological validity
Table 6a Airline service quality study - reference axis correlations from factor analysis

\begin{tabular}{lcccc}
\hline & Factor 1 & Factor 2 & Factor 3 & Factor 4 \\
\hline Factor 1 & 1.00000 & -0.47775 & -0.20050 & -0.13131 \\
Factor 2 & -0.47775 & 1.00000 & -0.21781 & -0.24360 \\
Factor 3 & -0.20050 & -0.21781 & 1.00000 & -0.15073 \\
Factor 4 & -0.13131 & -0.24360 & -0.15073 & 1.00000 \\
\hline
\end{tabular}

Table 6b Reference axis correlations, following PROMAX rotated factor analysis, service quality study, retail pharmacies

\begin{tabular}{lccc}
\hline & Factor I & Factor 2 & Factor 3 \\
\hline Factor 1 & 1.00000 & -0.46250 & -0.31899 \\
Factor 2 & -0.46250 & 1.00000 & -0.32238 \\
Factor 3 & -0.31899 & -0.32238 & 1.00000 \\
\hline
\end{tabular}

are high; and, that only in the case of discriminant validity the instrument is found wanting. These findings tend to be in line with those of Carman (1990), Babakus \& Boller (1991), and Pitt, Oosthuizen \& Morris (1992).

\section{Limitations of the study}

Like all projects of a similar nature, this study has some obvious limitations which signal caution to the generalization of the findings. Firstly, the study was limited by the use of only four organizations within the Larsson-Bowen framework. Even if one accepts the allocation of particular organizations to the framework, the study is still in reality representative of those organizations only. Similarly, apart from the limitations of sampling, the studies conducted all utilized some form of mail survey. A notorious disadvantage of mail surveys is that they invariably induce a response bias - respondents at severe ends of the satisfaction spectrum tend to respond disproportionately (those who are delighted, and those who are angry). Finally, the studies were in a sense limited by the fact that the respondents were assumed by the questionnaire to be literate, firstly, and capable of understanding the English language, secondly. The SERVQUAL questionnaires used were all, only, in English. In a multicultural South Africa today that will not always be a reasonable assumption.

\section{Recommendations}

A number of aspects learned from this study may be beneficial to researchers in this area in the future, and thus serve as recommendations. In no particular order the following recommendations can be made.

\section{Addition of items to the SERVQUAL questionnaire}

Frequently, managers within industries may believe that their organizations are so unique that basic principles do not apply. In conducting service quality research, it is frequently easy then, to gloss over the SERVQUAL questionnaire, and assert that it does not capture all the dimensions of service quality in that particular industry. The 22 items then become many more, and the original purposes of the developers in 
producing the instrument, namely elegance, genericism, and brevity, is lost. This was illustrated well in the case of the airline service quality study. A number of essentially repetitive questions may have resulted in very high coefficient alphas, without necessarily increasing the quality of measurement (See Dillon, Madden \& Firtle, 1987 for an explanation of why this occurs). The effects of this on validity were also obvious in the subsequent factor analysis.

Obviously wording will have to be changed depending on the type of organization and industry, in South Africa translation will frequently be required, and certainly items may have to be deleted or added. The recommendation is that this be done very carefully. Perhaps even more importantly, when the SERVQUAL questionnaire is used in commercial settings by marketing researchers, clients should be aware of the implications, and insist more rigidly on rigorous monitoring and assessment, and eventual alteration, of the instrument used.

\section{Measuring service quality in South Africa}

This series of studies was conducted among literate, mainly white South Africans, with at least a command of the English language. In the future it may be important to develop ways of measuring service quality in other languages, while still maintaining reliability and validity. It will also be important in third-world countries to adapt marketing measures, of which the SERVQUAL questionnaire is one, which can be communicated to illiterate consumers.

That the reliability and validity of the SERVQUAL questionnaire be established in using it in commercial marketing research applications

It is likely that the SERVQUAL questionnaire will be used increasingly to measure service quality in organizations both in South Africa and the rest of the world in the future. Its reliability and validity have been reasonably well demonstrated both internationally and in South Africa. However it is recommended, for three reasons, that in commercial applications a check still be maintained on reliability and validity. First, this is simply good research practice, and it is fair that clients demand this of their marketing research suppliers. Second, questionable results in this regard may point to inadequate research methodology and practice. Or, thirdly, questionable results may shed light on interesting situations within the company, or its markets. Low alpha coefficients, for example, may be a sign that the company faces two or more distinct market segments, who rate the SQI, or by dimension, very differently. These may be different types of customer, as for example the students versus the executives in the graduate business school study. Likewise, an organization surveying customers at different geographic locations, may find that alphas are low because of the very different nature of service quality at the various branches. Whatever the reasons for low reliability and validity in a particular study, in all likelihood interesting and useful insights may be given to managers.

\section{Directions for future research}

Some directions for possible future research in the area of service quality within organization typologies, under South African conditions, are suggested. There has not been a great deal of research work done in the area of service quality in South Africa, so in general there is scope for much continued effort in this regard. Additional replications alone will provide a great deal of further insight. However, it is in the areas of communication, and cross-cultural comparisons that the richest advances may be made. If the SERVQUAL questionnaire is to be translated, it will be important to ascertain what effects (accurate) translation have on its reliability. Recently some interesting work has also been done on the effects of using iconic and graphic rating scales, and simple graphic instructions on an adapted version of the SERVQUAL questionnaire (Labadie \& Harrison, 1991). Where much marketing research will have to be done with illiterate consumers as respondents in South Africa in the future, ways of communicating with them will need to be the focus of a great deal of research. In its present form, the SERVQUAL questionnaire requires a reasonably high degree of literacy, whether it be communicated to the respondent by mail, telephone or personally.

Cross-cultural comparisons of service quality perceptions will also provide for rewarding research in South Africa. Do different cultural groups have different expectations and perceptions of service quality of different providers? Are the dimensions of service quality equally important to these different groups? These are questions which will need to be answered if service quality is to be measured and managed in South Africa in the future.

\section{References}

Albrecht, K. 1988. At America's service. Homewood, Ill.: Dow Jones-Irwin.

Assael, H. \& Kamins, M.A. 1989. Effects of appeal type and involvement on product disconfirmation: a cognitive response approach through product trial, Journal of Academy of Marketing Science, 17(3): 197-207.

Babakus, E. \& Boller, G.W. 1992. An empirical assessment of the SERVQUAL scale, Journal of Business Research, 24(3): 253268.

Baum, H.M. 1990. White-collar quality comes of age, The Journal of Business Strategy, March-April: 34-37.

Becker, W.S. \& Wellins, R.S. 1990. Customer-service perceptions and reality. Training and Development Journal, 44(3): 49-51.

Berry, L.L., Parasuraman, A. \& Zeithaml, V.A. 1988. The service quality puzzle, Business Horizons, 31(5): 35-43.

Berry, L.L., Zeithaml, V.A. \& Parasuraman, A. 1985. Quality counts in services, too, Business Horizons, May-June: 14-20.

Berry, L.L., Zeithaml, V.A. \& Parasuraman, A. 1990. Five imperatives for improving service quality, Sloan Management Review, 31(4): 29-38.

Bertrand, K. 1989. In service, perception counts. Business Marketing, 74(4): 44-50.

Bitner, M.J. 1990. Evaluating service encounters: the effects of physical surroundings and employee responses, Journal of Marketing. 54: 69-82.

Bolton, R.N. \& Drew, J.H. 1991. A multistage model of customer's assessments of service quality and value, Journal of Consumer Research, 17: 375-384.

Boothe, R. 1990. Who defines quality in service industries? Quality Progress, 23(2): 65-67.

Bowen, D.E. \& Schneider, B. 1988. Services marketing and management: implications for organisational behavior. In Staw, B.M. \& Cummings, L.L., eds. Research in organizational behavior, Vol. 10. Greenwich CT: JAI Press Inc. 
Brensinger, R.P. \& Lambert, D.M. 1990. Can the SERVQUAL scale be generalized to business-to-business services? Proceedings of the Summer Educators Conference. Chicago, Ill.: American Marketing Association.

Brown, S.W. \& Gaulden, C.F. (Jr.) 1984. Replication and theory development. In Brown, S.W. \& Fisk, R.P. eds. Distinguished essays in marketing theory. New York, NY: John Wiley and Sons.

Brown, S.W. \& Swartz, T.A. 1989. A gap analysis of professional service quality, Journal of Marketing, 53(2): 92-98.

Buswell, D. 1983. Measuring the quality of in-branch service quality, International Journal of Bank Marketing, 1(1): 26-41.

Buzzell, R.D. \& Gale, B.T. 1987. The PIMS principles. New York, NY: The Free Press.

Cadotte, E.R., Woodruff, R.B. \& Jenkins, R.L. 1987. Expectations and norms in models of consumer satisfaction, Joumal of Marketing Research, 24: 305-314.

Cardozo, R.N. 1965. An experimental study of consumer effort, expectation and satisfaction, Journal of Marketing Research, 2: 244.

Carlzon, J. 1987. Moments of truth: new strategies for today's customer-driven economy. Cambridge, Mass.: Ballinger.

Carman, J M. 1990. Consumer perceptions of service quality: an assessment of the SERVQUAL dimensions, Journal of Retailing, 66(1): 33-55.

Churchill, G.A. (Jr.) 1979. A paradigm for developing better measures of marketing constructs, Journal of Marketing Research, 16 64-73.

Churchill, G.A. (Jr.) \& Surprenant, C. 1982. An investigation into the determinants of customer satisfaction, Journal of Marketing Research, 19(4): 244-249.

Cronbach, L.J. 1951. Coefficient alpha and the internal structure of tests, Psychometrika, 16(3): 297-333.

Cronin, J.J. (Jr.) \& Morris, M.H. 1989. Satisfying customer expectations: the effect on conflict and repurchase intentions in industrial marketing channels, Journal of Academy of Marketing Science, 17(1): 41-49.

Cronin, J.J. \& Taylor, S.A. 1992. Measuring service quality: a reexamination and extension, Journal of Marketing, 56: 55-68.

Crosby, P.B. 1979. Quality is free: the art of making quality certain. New York, NY: New American Library.

Davidow, W.H. \& Uttal, B. 1989. Total customer service - the ultimate weapon. New York, NY: Harper and Row.

Day, G.S. \& Wensley, R. 1988. Assessing advantage: a framework for diagnosing competitive superiority, Journal of Marketing, 52: $1-20$.

De Souza, G. 1989. Now service businesses must manage quality, Journal of Business Strategy, 10(3): 21-25.

Dillon, W.R., Madden, T.J. \& Firtle, N.H. 1987. Marketing research in a marketing environment. St. Louis, Miss.: Timers Mirror/ Mosby College Publishing.

Finn, D.W. \& Lamb, C.W. 1991. An evaluation of the SERVQUAL scales in a retailing setting, Advances in Consumer Research, 18 (Forthcoming).

Garvin, D.A. 1983. Quality on the line, Harvard Business Review, 61: 65-73.

Gronroös, C. 1978. A service-oriented approach to marketing of services, European Journal of Marketing, 12(8): 588-601.

Gronroös, C. 1982. Strategic management and marketing in the services sector. Working paper. Helsingfors: Swedish School of Economics and Business Administration.

Gronroös, C. 1984. A service quality model and its marketing implications, European Journal of Marketing, 18(4): 36-44.

Gronroös, C. 1988. Service quality: the six criteria of good perceived service quality, Review of Business, 9: 10-13.

Hensel, J.S. \& Baumgarten, S.A. 1988. Managing patient perceptions of medical practice service quality, Review of Business, 9: 23-26.
Heskett, J.L. 1987. Lessons in the service sector, Harvard Business Review, 87: 118-126.

Holbrook, M.B. \& Corfman, K.P. 1985. Quality and value in the consumption experience: Phaedrus rides again. In Jacoby, J. \& Olson, J.C. Perceived quality: how consumers view stores and merchandise. Lexington, MA: Lexington Books.

Hunt, H.K. 1977. CS/D - overview and future research directions. In Hunt, H.K. ed. Conceptualization and measurement of consumer satisfaction and dissatisfaction. Cambridge, Mass.: The Marketing Science Institute.

Kamins, M.A. \& Assael, H. 1987. Moderating disconfirmation of expectations through the use of two-sided appeals: a longitudinal approach, Journal of Economic Psychology, 8(2): 237-253.

Kierl, C. \& Mitchell, P. 1990. How to measure service quality, Industrial Marketing Digest, 15(1): 35-46.

Labadie, J. \& Harrison, R. 1991. SERVQUAL: reliability and validity of a graphic alternative. Proceedings of the 2 nd Annual South African Marketing Educators Conference. Stellenbosch: University of Stellenbosch, November 14-15.

LeBlanc, G. \& Nguyen, N. 1988. Customers' perceptions of service quality in financial institutions, International Joumal of Bank Marketing, 6(4): 7-18.

Leonard, F.S. \& Sasser, W.E. 1982. The incline of quality, Harvard Business Review, 60: 183-191.

Lewis, B.R. 1989. Quality in the service sector, International Journal of Bank Marketing, 7(5): 4-12.

Lewis, B.R. 1991. Service quality: an international comparison of bank customers' expectations and perceptions, Journal of Marketing Management, 7(1): 47-62.

Lewis, R.C., and Booms, B.H. 1983. The marketing aspects of service quality. In Berry, L., Shostack, G.L. \& Upah, G. eds. Emerging perspectives on services marketing. Chicago, IL: American Marketing Association.

Liswood, L.A. 1989. Five barriers to service quality, Bank Marketing, 21(9): 38-39.

Lovelock, C.H. 1980. Towards a classification of services. In Lamb, C.W. \& Dunne, P.M. eds. Theoretical developments in marketing. Chicago, Ill.: American marketing Association.

Lovelock, C.H. 1983. Classifying services to gain strategic marketing insights, Journal of Marketing, 47(3): 9-20.

Luchs, R. 1986. Successful businesses compete on quality - not costs, Long Range Planning, 19: 12-17.

Mangold, W.G. \& Babakus, E. 1990. Monitoring service quality, Review of Business, 11 (4): 21-27.

Martin, J.M. 1987. Developing a strategy for quality, Manufacturing Engineering, August: $40-45$.

Mills, P.K. 1986. Managing service industries: organizational practices in a postindustrial economy. Cambridge, MA.: Ballinger.

Nel, D. \& Boshoff, C. 1991. Service quality perceptions in banking and insurance brokerage industries. Proceedings of the 2 nd Annual South African Marketing Educators Conference. Stellenbosch: University of Stellenbosch, November 14-15.

Oliver, R.L. \& Bearden, W.O. 1985. Disconfirmation processes and consumer evaluations in product usage. Journal of Business Research, 13(3): 235-246.

Oliver, R.L., and DeSarbo, W.S. 1988. Response determinants in satisfaction judgments, Joumal of Consumer Research, 14(4): 495507.

Oliver, R.L. \& Swan, J.E. 1989. Consumer perceptions of interpersonal equity and satisfaction in transactions: a field survey approach, Journal of Marketing, 53(2): 21-35.

Oliver, R.L. 1980. A cognitive model of the antecedents and consequences of satisfaction decisions, Journal of Marketing Research, 42(4): $460-469$. 
Oliver, R.L. 1981. Measurement and evaluation of satisfaction processes in retail settings, Journal of Retailing, 57: 25-48.

Oliver, R.L. 1989. Processing of the satisfaction response in consumption: a suggested framework and research propositions, Journal of Consumer Satisfaction, Dissatisfaction and Complaining Behavior, 2: 1-16.

Olson, J.C. \& Dover, P. 1976. Effects of expectations, product performance, and disconfirmation on belief elements of cognitive structures. In Anderson, B.B. ed. Advances in consumer research, vol. 3. Provo, UT: Association for Consumer Research.

Olson, J.C. \& Dover, P. 1979. Disconfirmation of consumer expectations through product trial, Joumal of Applied Psychology, 46: 375-384.

Olshavsky, R.W. 1985. Perceived quality in consumer decision making: an integrated theoretical perspective. In Jacoby, J. \& Olson, J. eds. Perceived quality. Lexington, Mass.: Lexington Books.

Olshavsky, R.W. \& Miller J.A. 1972. Consumer expectations, product performance and perceived product quality, Journal of Marketing Research, 9: 19-21.

Parasuraman, A., Zeithaml, V.A. \& Berry, L L. 1985. A conceptual model of service quality and its implications for future research, Journal of Marketing, 41-55.

Parasuraman, A., Zeithaml, V.A. \& Berry, L.L. 1988. SERVQUAL: a multiple-item scale for measuring customer perceptions of service quality, Journal of Retailing, 64: 12-40.

Parasuraman, A., Zeithaml, V.A. \& Berry, L L. 1991. Refinement and reassessment of the SERVQUAL scale, Journal of Retailing, 67(4): 420-450.

Parasuraman, A., Zeithaml, V.A. \& Berry, L L. 1994. Alternative scales for measuring service quality: a comparative assessment based on psychometric and diagnostic criteria, Journal of Retailing, 70(3): 201-230.

Peter, J.P. 1981. Construct validity: a review of basic issues and marketing practices, Journal of Marketing Research, 23(5): 133-145.

Pitt, L.F., Oosthuizen, P. \& Morris, M.H. 1992. Service quality in a high-tech industrial market: an application of SERVQUAL, American Marketing Association Educators' Proceedings: Enhancing
Knowledge Development in Marketing. Robert P Leone, R.P., Kk mar, V. eds. Chicago, IL: American Marketing Association, August, 46-53.

Porter, M.E. 1985. Competitive advantage: creating and sustaining superior performance. New York, NY: Free Press.

Powers, T.L. 1988. Identify and fulfil customer service expectations, Industrial Marketing Management, 17, 273-276.

Richardson, B.A. \& Robinson, C.G. 1986. The impact of internal marketing on consumer service in a retail bank, International Journal of Bank Marketing, 4(5): 3-30.

Swartz, T.A. \& Brown, S.W. 1989. Consumer and provider expectations and experience in evaluating professional service quality, Journal of the Academy of Marketing Science, 17(2): 189-195.

Tabacchi, M.H. \& Marshall, R.C. 1988. Consumer perceptions of inflight food service, Cornell Hotel \& Restaurant Administration Quarterly, 28(4): 20-23.

Takeuchi, H. \& Quelch, J.A. 1983. Quality is more than making a good product, Harvard Business Review, 61: 139-145.

Tansuhaj, P., Wong, J. \& McCullough, J. 1987. Internal and extemal marketing: effects on consumer satisfaction in banks in Thailand, International Journal of Bank Marketing, 5(3): 73-83.

Thompson, P., DeSouza, G. \& Gale, B.T. 1985. The Strategic management of service quality, PIMSLETTER no. 33, Cambridge Mass.: Strategic Planning Institute.

Tse, D.K. \& Wilton, P.C. 1988. Models of customer satisfaction: an extension, Journal of Marketing Research, 25(2): 204-212.

Uttal, B. 1987. Companies that service you best. Fortune, 7: 98116.

Zeithaml, V.A., Berry, L.L. \& Parasuraman, A. 1988. Communication and control processes in the delivery of service quality, Journal of Marketing, 52: 35-48.

Zeithami, V.A., Parasuraman, A. \& Berry, L.L. 1990. Delivering quality service. New York, NY: The Free Press.

Zeithaml, V.A., Berry, L.L. \& Parasuraman, A. 1991. The nature and determinants of customer expectations of service, Marketing Science Institute, Working Paper No. 91-113.

\title{
Fourth International Organizational Behaviour Teaching Conference
}

\author{
December 15-18 1997
}

\author{
Graduate School of Business \\ University of Cape Town
}

This is a unique international conference which allows academics, training and development practitioners, management consultants, managers and students to discuss, debate and share through workshops, focus sessions and conversation hours around three subthemes:

- international perspectives on OB teaching;

- pedagogical issues raised by cultural diversity, employment equity and affrimative action; and

- organizational redesign and new organizational forms in the 21 st century.

Submit a proposal for a 60,90 or 120 minute workshop per 30 minute focus session and for poster sessions. We welcome suggestions and nominations for conversational hours and pre/post-conference work sessions.

For more information contact Pat Boulton, IOBT '97, Graduate School of Business, University of Cape Town, Private Bag, Rondebosch 7700, South Africa; or fax a copy to Pat Bolton at 2721 215510, or e-mail: phoulton@gsb2.uct.ac.za. 